It has been demonstrated that, in X-irradiated aqueous solutions of histidine ${ }^{3}$ and probably tyrosine ${ }^{4}$, decarboxylation occurs to a very low amount. This is possible, because in aromatic amino-acids there are a number of sites to be attacked by the free radicals produced from the water. Our results with rather small $G$-value indicate that 5-HTP (an aromatic amino-acid too) behaves similarly.

It has been noted ${ }^{5}$ that 5 -HT in aqueous solution undergoes many changes in its structure under the influence of different oxidizing agents. Taking into account the low conversion-rate of 5-HTP to 5-HT, one should consider the possibility of transformations of 5-HT molecules when under the influence of $\mathrm{X}$-irradiation. It seems to us likely that the low amount of 5-HT formed could be partly explained by the action of the various oxidizing species produced by the X-rays.

We wish to thank Dr. A. J. Swallow, London, for his interest and helpful suggestions. 5-HTP was kindly supplied by the National Drug Company, Philadelphia, Pennsylvania.

M. Jović

Z. SUPEK

Biology Division,

Institute Rudljer Bošković,

Zagreb, Bijenička 54, Yugoslavia.

'Doepfner, W., and Cerletti, A., Experientia, 14, 376 (1958).

2 Amin, A. H., Crawford, T. B. B., and Gaddum, J. H., J. Physiol., 126, 596 (1954).

${ }^{3}$ Flemming, K., Arch. Exp. Path. Pharmak., 239, 425 (1960).

- Rowbottom, J., J. Biol. Chem., 212, 877 (1955).

'Eriksen, N., J. Biol. Chem., 235, 1662 (1960).

\section{Lanthionine Formation in Keratin}

REACTION of wool keratin with solutions of alkalis or potassium cyanide leads to the elimination of one of the sulphur atoms of the dithio bond of the eystine residues with the formation of a thioether (lanthionine) linkage :

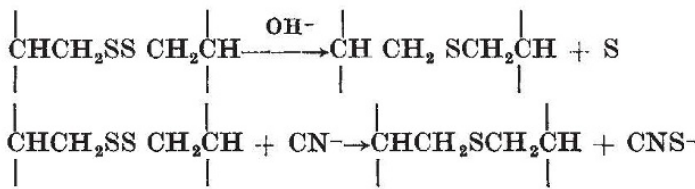

It is considered that the reaction with cyanide ions, which overall may be represented by equation (2), can follow two possible courses :

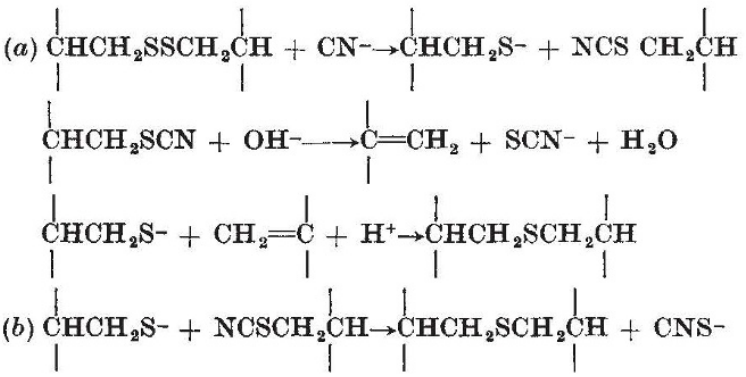

The $\beta$-elimination reaction $(a)$ was first proposed by Swan $^{1}$, who later suggested the possibility of lanthionine formation by $\mathrm{SCN}$ - displacement ${ }^{2}$ without removal of $\beta$-hydrogen atoms. This was confirmed by Earland and Raven ${ }^{3}$, who studied the reaction of $\mathrm{N}$-mercaptomethylpolyhexamethyleneadipamide disulphide with cyanide ions, and showed that a thio- ether bond is formed under conditions identical to those which produce lanthionine in wool :

$$
\underset{\mid}{\operatorname{NCH}} \mathrm{SSCH}_{2} \mathrm{~N}+\mathrm{CN}^{-} \rightarrow \underset{\mathrm{N}}{\mid} \mathrm{CH}_{2} \mathrm{~S} \mathrm{CH}_{2} \mathrm{~N}+\mathrm{CNS}-
$$

Since $\beta$-elimination is impossible, it must be concluded that a reaction such as $(b)$ is very probably an important route for lanthionine formation in wool.

On the other hand, in the alkaline reaction, Swan has shown the importance of a $\beta$-elimination mechanism :

$$
\underset{\mathrm{CHCH}_{2} \mathrm{SS} \mathrm{CH}}{\mid} \underset{\mid}{\mathrm{CH}}+\mathrm{OH}^{-} \rightarrow \underset{\mathrm{CHCH}_{2} \mathrm{SS}^{-}}{\stackrel{\mathrm{CH}_{2}}{\mid} \mathrm{CH}_{2} \mathrm{~S} \mathrm{CH}_{2} \mathrm{CH}}+\underset{\mid}{\mathrm{CH}_{2}}=\underset{\mid}{\mathrm{C}}+\mathrm{H}_{2} \mathrm{O}
$$

since $\alpha \alpha^{\prime}$ dimethylcystine is degraded only extremely slowly under these conditions, compared with free cystine.

The reaction of N-mercaptomethylpolyhexamethyleneadipamide with alkalis has now been examined, as it is probably a better model for wool ${ }^{5}$ than Swan's compounds, in that the reaction, as with wool, is heterogeneous, giving the ruptured disulphide residues a greater chance to re-unite in a lanthionine linkage.

$2.00 \mathrm{gm}$. of disulphide (sulphur, $4 \cdot 20$ per cent) were boiled under reflux for $5 \mathrm{hr}$. with $400 \mathrm{ml}$. of the solution of alkali. After reaction, the solid product was collected, washed with water and dried in vacuo. The results obtained are given in Table 1 .

\begin{tabular}{|c|c|c|c|c|c|}
\hline Solution & $p \mathrm{H}$ & $\begin{array}{c}\text { Wt. } \\
\text { loss } \\
\text { (per } \\
\text { cent) }\end{array}$ & $\begin{array}{l}\text { Sulphur } \\
\text { in } \\
\text { product } \\
\text { (per } \\
\text { cent) }\end{array}$ & $\begin{array}{c}\text { Disulph- } \\
\text { ide } \\
\text { sulphur } \\
\text { (per } \\
\text { cent) }\end{array}$ & $\begin{array}{c}\mathrm{NH}_{2} \\
\text { m.equiv } \\
100 \mathrm{gm} .\end{array}$ \\
\hline $\begin{array}{l}0.10 M \mathrm{Na}_{2} \mathrm{HPO}_{4} \\
0 \cdot 05 M \mathrm{Na}_{2} \mathrm{~B}_{4} \mathrm{O}_{7} \\
0 \cdot 10 M \mathrm{Na}_{8} \mathrm{CO}_{3} \\
0 \cdot 10 M \mathrm{Na}_{2} \mathrm{CO}_{3}{ }^{*} \\
0 \cdot 10 M \mathrm{NaOH}^{2}\end{array}$ & $\begin{array}{r}\overline{8} \\
8 \cdot 0 \\
10 \cdot 2 \\
10 \cdot 5 \\
12 \cdot 0\end{array}$ & $\begin{array}{c}\overline{1 \cdot 0} \\
0 \\
2 \cdot 5 \\
11 \cdot 0 \\
35 \cdot 0\end{array}$ & $\begin{array}{l}4 \cdot 20 \\
3 \cdot 99 \\
4 \cdot 14 \\
3 \cdot 70 \\
3 \cdot 39 \\
2 \cdot 23\end{array}$ & $\begin{array}{l}4 \cdot 07 \\
4 \cdot 26 \\
4 \cdot 27 \\
3 \cdot 94 \\
3 \cdot 28 \\
1 \cdot 90\end{array}$ & $\begin{array}{l}1 \cdot 5 \\
1 \cdot 5 \\
1 \cdot 6 \\
2 \cdot 3 \\
2 \cdot 7 \\
4 \cdot 7\end{array}$ \\
\hline
\end{tabular}
The analytical methods used have been described previously ${ }^{3}$.

It is shown that a lanthionine type of reaction does not occur when the $\beta$ CH group is replaced by nitrogen, which must be regarded as strong supporting evidence for the $\beta$-elimination mechanism, and against mechanisms which involve formation by direct attack on the $\alpha$-carbon atom ${ }^{6}$.

We thank the Wool Textile Research Council for financial assistance with this work.

C. Earland

D. J. RAVEN

Department of Textile Industries, Institute of Technology,

$$
\text { Bradford. }
$$

'Swan, J. M., Proc. Intern. Wool Textile Res. Conf., Austral., C-25 (1955)

${ }^{2}$ Swan, J. M., Current Trends in Heterocyclic Chemistry, 65 (Butterworths, 1958).

${ }^{3}$ Earland, C., and Raven, D. J., J. Amer. Chem. Soc., 80, 3430 (1958). "Swan, J. M., Nature, 179, 965 (1957).

Earland, C., and Raven, D. J., Proc. Second Intern. Wool Textile Research Conf. England, J. Text. Inst., 51, T 678 (1960).

- Zahn, H., Kunitz, F.-W., and Hildebrand, D., Proc. Second Intern. Wool Textile Research Conf. England, J. Text. Inst., 51, T 740 